\title{
New Zealand
}

National Cancer Institute

\section{Source}

National Cancer Institute. New Zealand. NCI Thesaurus. Code C16914.

A country in the Pacific, comprised of islands in the South Pacific Ocean, southeast of Australia. 